\title{
The effect of sets and repetitions of the spirometer by flow in cardiorespiratory parameters
}

\author{
Efeito das séries e repetições do inspirômetro a \\ fluxo nos parâmetros cardiorrespiratórios
}

\author{
Bruno Martinelli ${ }^{[a]}$, Giovana Damasceno e Souza ${ }^{[b]}$, Mariana Dela Coleta Ricci ${ }^{[c]}$, Camila Gimenes ${ }^{[\mathrm{d}]}$, \\ Marta Helena Souza De Conti ${ }^{[\mathrm{e}]}$, Silvia Regina Barrile ${ }^{[\mathrm{f}]}$
}

[a] Master's Degree in Medical Clinical Pathophysiology, Faculdade de Medicina de Botucatu (Medical College of Botucatu) Unesp, professor at the Physiotherapy course at the Universidade do Sagrado Coração (Sagrado Coração University), Bauru, SP - Brazil, e-mail: bruno.martinelli@usc.br

[b] Physiotherapist gradute from Universidade do Sagrado Coração (Sagrado Coração University), Bauru, SP - Brazil, e-mail: giovana.damasceno@yahoo.com.br

[c] Physiotherapist gradute from Universidade do Sagrado Coração (Sagrado Coração University), Bauru, SP - Brazil, e-mail: ma_dcr@yahoo.com.br

[d] PhD in Medical Clinical Pathophysiology, Universidade Estadual Paulista (Unesp/Botucatu), professor at the Physiotherapy course at the Universidade do Sagrado Coração (Sagrado Coração University), Bauru, SP - Brazil. e-mail: ca_gimenes@hotmail.com

[e] PhD in Medical Clinical Pathophysiology, Universidade Estadual Paulista (Unesp/Botucatu), professor at the Physiotherapy course at the Universidade do Sagrado Coração (Sagrado Coração University), Bauru, SP - Brazil, e-mail: madeconti@yahoo.com.br

[f] PhD in Medical Clinical Pathophysiology, Universidade Estadual Paulista (Unesp/Botucatu), professor at the Physiotherapy course at the Universidade do Sagrado Coração (Sagrado Coração University), Bauru, SP - Brazil, e-mail: srbarrile@gmail.com

\section{Abstract}

Introduction: The incentive spirometer helps pulmonary ventilation and the cardiorespiratory changes of its use are controversial. Objective: To evaluate the effect of sets and repetitions on cardiorespiratory parameters using a spirometer alinear flow (SAF). Materials and methods: The sample group consisted of 50 young people, healthy and sedentary. The evaluated parameters were: systolic blood pressure (SBP), 
diastolic (DBP), heart rate (HR), respiratory rate (RR), oxygen saturation $\left(\mathrm{SaO}_{2}\right)$, minute volume (VE), tidal volume (VT), vital capacity (VC), maximal inspiratory pressure $\left(\mathrm{Pi}_{\max }\right)$, maximal expiratory pressure $\left(\mathrm{Pe}_{\max }\right)$, and peak expiratory flow (PEF). The moments of study were: initial evaluations (M1); 3 sets of 10 repetitions using SAF (M2); 3 sets of 15 repetitions using SAF (M3); and final evaluation (M4). Statistical analysis was made by $t$ test, ANOVA and Tukey test $(\mathrm{p}<0.05)$. Results: SBP and HR decreased in M2 after the $2^{\text {nd }}$ set. In the $3^{\text {rd }}$ set, SBP and RR decreased. Comparing the initial and final variables in M2, SBP and RR decreased, and $\mathrm{Pe}_{\max }$ increased. After $1^{\text {st }}$ set in $\mathrm{M} 3, \mathrm{SBP}$ and $\mathrm{SaO}_{2}$ decreased. The $2^{\text {nd }}$ set: $\mathrm{SBP}, \mathrm{HR}, \mathrm{RR}$, and $\mathrm{SaO}_{2}$ decreased. After the $3^{\text {rd }}$ set: $\mathrm{SBP}, \mathrm{HR}, \mathrm{SaO}_{2}$, and $\mathrm{RR}$ decreased. Comparing the initial and final variables in $\mathrm{M} 3, \mathrm{SBP}$, HR, RR decreased, and $\mathrm{Pi}_{\max }$ and $\mathrm{Pe}_{\max }$ increased. Comparing M4 to M1, $\mathrm{Pi}_{\max }, \mathrm{Pe}_{\max }$, and VC increased, and RR decreased. Conclusion: There are changes in cardiorespiratory parameters after the use of a spirometer alinear flow, especially in the sets with more repetitions.

Keywords: Physiotherapy. Pulmonology. Respiratory therapy.

\section{Resumo}

Introdução: Os incentivadores respiratórios auxiliam na ventilação pulmonar e as modificações cardiorrespiratórias mediante seu uso ainda são discutidas. Objetivo: Avaliar efeito das séries e repetições com uso do inspirômetro alinear a fluxo (IAF) nos parâmetros cardiorrespiratórios. Materiais e métodos: A amostra foi composta de 50 jovens, saudáveis e sedentários. Os parâmetros avaliados foram: pressão arterial (PA), frequência de pulso (FP), frequência respiratória (FR), saturação (SatO $\left.{ }_{2}\right)$, volume minuto (VM), volume corrente (VC), capacidade vital $(C V)$, pressão inspiratória $\left(P i_{\text {máx }}\right)$, pressão expiratória $\left(P e_{\text {máx }}\right)$ e fluxometria. Os momentos foram: avaliações inicial (M1); uso do IAF em 3 séries de 10 repetições (M2); 3 séries de 15 repetições (M3); avaliação final (M4). A análise estatística se deu pelo teste " $t$ " de Student, ANOVA e Teste de Tukey $(p<0,05)$. Resultados: No M2, após a $2^{a}$ série houve diminuição da PAS e FP; na $3^{a}$ série: diminuição da PAS e FR. Comparando as variáveis iniciais e finais do M2, houve diminuição da PAS e FR, e aumento da Pe $e_{\max }$.No M3, 1a série, houve diminuição da PAS e $\mathrm{SatO}_{2}$. Na $2^{a}$ série: diminuição da PAS, FP, FR e SatO ${ }_{2}$. Após a $3^{a}$ série: diminuição da PAS, FP, $\mathrm{SatO}_{2}$ e FR. Comparando as variáveis iniciais e finais do M3, houve diminuição da PAS, FP, FR; aumento da Pi $i_{\text {máx }}$ e Pe $e_{\text {máx. }}$ Comparando M4 com M1, houve aumento da Pi $i_{\operatorname{máx}}$ e Pe $e_{\text {máx }}$ diminuição da FR e aumento da CV. Conclusão: Há alterações nos parâmetros cardiorrespiratórios após utilização do IAF, principalmente nas séries com maiores repetições.

Palavras-chave: Fisioterapia. Pneumologia. Terapia respiratória.

\section{Introduction}

The movement of gases in the lungs and tissues occurs by diffusion and its transport requires the work of respiratory and cardiac pumps. The internal respiratory function is related to the pulmonary functional role performed by the ventilation and circulation, and the external assures the pulmonary volume variations, which guarantee the gas exchanges of the body (1). The driving pressure of the respiratory system, generated by muscular contraction during inspiration, must overcome elastic and resistance forces to fill the lungs $(2,3)$. One of the techniques to reduce pulmonary complications and stimulate the respiratory function is the incentive spirometry, which aims to incite, by visual stimulus and auditory feedback, the maximal sustained inspiration, promote alveolar hyperinflation, help in the muscular respiratory function, and in the effectiveness of the pulmonary ventilation through the patient's resistance and spontaneous breathing $(4,5)$. Although the incentive spirometry is widely used among health professionals, there are still no appropriate clarifications on its effect on the sets and repetitions. Studies that verify the effects of the use of incentive spiromety in patients who underwent major interventions show that there are limitations in the research on its application $(6,7,8)$. However, the American Association for Respiratory Care (9) recommends standardization, and on the other hand, in clinical practice, its 
prescription becomes variable and the impacts of its use are unclear, which make it necessary to analyze the changes in the cardiorespiratoty parameters related to its use. Thus, the purpose of this study was to evaluate the effect of sets and repetitions on cardiorespiratory parameters with the use of a incentive spirometer alinear by flow.

\section{Materials and methods}

Sample

The non-probabilistic sample group was composed of 50 healthy individuals, college students. Written, informed consent was obtained from all subjects and approved by the Ethics in Research Committee of the Dean of Research and Graduate Studies of USC - Sagrado Coração University ( $n^{\circ}$ 190/09).

\section{Inclusion criteria}

This research included individuals of ages between 18 and 24, college students, regardless of sex or availability for the intervention.

\section{Exclusion criteria}

This research excluded individuals who smoke, were pregnant, carried pulmonary or systemic pathologies that involve the respiratory system, and did intense physical exercise more than three times per week.

\section{General procedures}

For the initial evaluation (M1) an evaluation sheet was used to record personal information, life and social habits, anthropometrical measurements - digital anthropometric scale FILIZOLA ${ }^{\circledR}(10,11,12)$, blood pressure measurements - sphygmomanometer and stethoscope Premium ${ }^{\circledR}$ brand (13), respiratory measurements such as: fluxometry - Peak flow assess full range HS710-012 ADT - Respironics ${ }^{\circledR}$ (14), inspiratory $\left(\mathrm{Pi}_{\max }\right)$ and expiratory $\left(\mathrm{Pe}_{\max }\right)$ pressure - Comercial Médica ${ }^{\circledR}(15)$, ventilometry - analogic ventilometer
Whright Mark $8^{\circledR}(16)$, pulse oximetry - Onix ${ }^{\circledR}$ (17), and space to fill out the time supporting the spheres and the quantity of spheres supported resulting from the use of the incentive inspirometer Respiron ${ }^{\circledR}(\mathrm{ad}-$ justment ring at the zero position).

It was established a five-minute rest prior to the measurement of the blood pressure (BP), oxygen saturation $\left(\mathrm{SaO}_{2}\right)$, heart rate (HR), respiratory rate (RR), then the $\mathrm{Pi}_{\max }$ and $\mathrm{Pe}_{\max }$ were checked, subsequently the peak expiratory flow (PEF) was measured, and finally the vital capacity (VC), minute volume (VE), and tidal volume (VT) were identified. For the procedure, the volunteer individuals were positioned in a sitting position (triple $90^{\circ}$ angle between the trunk, hip, and ankle).

\section{Sessions}

Determining the sets and repetitions was based on the American Association for Respiratory Care (9), and one to three sets of 10 to 15 repetitions were evaluated in different moments. For that, respiration happened orally utilizing a nose clip, doing the necessary repetitions corresponding to each set and supporting the spheres as long as possible $(9,17)$.

At the second moment (M2), 7 days after M1, 1, 2 , and 3 sets of 10 repetitions were done utilizing the same incentive inspirometer. The interval time between the sets was 1 minute. And 5 minutes after the sets the $\mathrm{BP}, \mathrm{HR}, \mathrm{SaO}_{2}$, and $\mathrm{RR}$ were checked. In the beginning and at the end of $\mathrm{M} 2$ the $\mathrm{BP}, \mathrm{HR}$, $\mathrm{SaO}_{2}, \mathrm{RR}$, maximum respiratory pressures, $\mathrm{VC}$, and VE were assessed.

At the third moment (M3), 14 days after M1, the same evaluation criteria was applied, however, 1, 2, and 3 sets of 15 repetitions were done.

At the fourth moment (M4) a final evaluation was performed, following the evaluation criteria used at M1.

\section{Statistical analysis}

The values were stated in average and standard deviation and in absolute and relative frequency. The variance test (ANOVA) and Turkey test (18) were used for repetitive measurements, utilizing the Pacotico software 5.3 version, and the Student " $t$ " test for initial and final measurements in each 
session and comparison between the three phases. The considered significance level was $\mathrm{p}<0.05$.

\section{Results}

Out of the 50 individuals studied, 10 (20\%) were male and 40 (80\%) were female, the average age was $20.98 \pm 1.66$, the average height was $1.67 \pm 0.08 \mathrm{~cm}$, weight $67 \pm 17.25 \mathrm{~kg}$ and body mass index $23.65 \pm$ $4.91 \mathrm{~kg} / \mathrm{m}^{2}$.

The Table 1 shows the behavior of the cardiorespiratory variables in the three sets of ten repetitions (M2).

It was noted at M2 after the $2^{\text {nd }}$ set, in comparison with the initial values at this same moment, a decrease in the systolic blood pressure (SBP) from $111.8 \pm 12.96$ to $109.16 \pm 15.16 \mathrm{~mm} \mathrm{Hg}(\mathrm{p}=0.02)$ and in the HR from $81.42 \pm 11.49$ to $79.06 \pm 10.63 \mathrm{bpm}$ ( $p=0.04$ ). And after the $3^{\text {rd }}$ set there was a decrease in the SBP from $111.8 \pm 12.96$ to $107.4 \pm 16.3 \mathrm{~mm} \mathrm{Hg}$ ( $\mathrm{p}=0.003$ ) and in the RR from $15.92 \pm 3.55$ to 15.08 $\pm 3.57 \mathrm{rpm}(\mathrm{p}=0.01)$. Comparing the initial and final variables in M2, there was a decrease in the SBP from $111.8 \pm 12.96$ to $107.88 \pm 12.65 \mathrm{~mm} \mathrm{Hg}$ ( $\mathrm{p}=0.0002$ ) and in the RR from $15.92 \pm 3.55$ to $15.06 \pm 3.65 \mathrm{rpm}$ $(\mathrm{p}=0.02)($ Table 1$)$.
Comparing M1 and the initial values at M2, there was an increase in the $\mathrm{Pi}_{\max }$ from $66.2 \pm 26.37$ to $71.68 \pm$ $24.69 \mathrm{cmH}_{2} \mathrm{O}(\mathrm{p}=0.017)$ and in the $\mathrm{Pe}_{\max }$ from $58.04 \pm$ 25.26 to $62.4 \pm 24.69 \mathrm{cmH}_{2} \mathrm{O}(\mathrm{p}=0.01)$.

In the respiratory pressure measurements, comparing the initial and final variables at M2, there was an increase in the $\mathrm{Pe}_{\max }$ from $62.4 \pm 24.69$ to $65.76 \pm$ $25.88 \mathrm{cmH}_{2} \mathrm{O}(\mathrm{p}=0.005)$.

At M3, after the $1^{\text {st }}$ set, comparing to the initial evaluation in the same moment, there was a decrease in the SBP from $110.52 \pm 13.55$ to $106.48 \pm 12.38 \mathrm{~mm}$ $\mathrm{Hg}(\mathrm{p}=0.0001)$ and in the $\mathrm{SaO}_{2}(\%)$ from $97.46 \pm 1.01$ to $96.84 \pm 1.47(p=0.004)$. After the $2^{\text {nd }}$ set there was a decrease in the SBP from $110.52 \pm 13.55$ to $107.82 \pm$ $13.60 \mathrm{~mm} \mathrm{Hg} \mathrm{(} \mathrm{p}=0.02)$, HR from $82.02 \pm 11.40$ to $77.9 \pm 9.39 \mathrm{bpm}(\mathrm{p}=0.0001)$, RR from $16.28 \pm 3.91$ to $15.36 \pm 385 \mathrm{rpm}(\mathrm{p}=0.009)$, and $\mathrm{SaO}_{2}(\%)$ from $97.46 \pm 1.01$ to $96.94 \pm 1.67(p=0.03)$. And after the $3^{\text {rd }}$ set there was a decrease in the SBP from $110.52 \pm$ 13.55 to $106.88 \pm 13.56 \mathrm{~mm} \mathrm{Hg}(\mathrm{p}=0.0009)$, HR from $82.02 \pm 11.40$ to $79.06 \pm 9 \mathrm{bpm}(\mathrm{p}=0.01), \mathrm{SaO}_{2}$ from $97.46 \pm 1.01$ to $96.8 \pm 2.09$ ( $\mathrm{p}=0.01)$, and RR from $16.28 \pm 3.91$ to $15.28 \pm 3.45(\mathrm{p}=0.01)$. Comparing the initial and final variables at M3, there was a decrease in the SBP from $110.52 \pm 13.55$ to $106.48 \pm$ $14.29 \mathrm{~mm} \mathrm{Hg}(\mathrm{p}=0.0006)$, HR from $82.02 \pm 11.4$ to

Table 1 - Comparison between the cardiorespiratory variables: initial, final, and during the execution of each of the three sets of ten repetitions - M2.

\begin{tabular}{|c|c|c|c|c|c|c|c|c|c|}
\hline \multirow[b]{2}{*}{ Variables } & \multirow{2}{*}{$\begin{array}{c}\text { Initial } \\
\text { Evaluation } \\
\text { (at rest) }\end{array}$} & \multicolumn{6}{|c|}{ Sets } & \multirow{2}{*}{$\begin{array}{l}\text { Final } \\
\text { Evaluation } \\
\text { (at rest) }\end{array}$} & \multirow{2}{*}{$\begin{array}{c}\mathrm{p}^{\dagger \dagger} \\
\text { Value }\end{array}$} \\
\hline & & $\begin{array}{l}1^{\text {st }} \\
\text { Set }\end{array}$ & $\begin{array}{c}p^{*} \\
\text { Value }\end{array}$ & $\begin{array}{l}2^{\text {nd }} \\
\text { Set }\end{array}$ & $\begin{array}{c}\mathbf{p}^{\dagger} \\
\text { Value }\end{array}$ & $\begin{array}{l}3^{\text {rd }} \\
\text { Set }\end{array}$ & $\begin{array}{c}p^{\star *} \\
\text { Value }\end{array}$ & & \\
\hline SBP & $\begin{array}{c}111.8 \pm \\
12.96\end{array}$ & $\begin{array}{c}110.32 \pm \\
13.31\end{array}$ & 0.18 & $\begin{array}{c}109.16 \pm \\
15.16\end{array}$ & $0.02^{+}$ & $\begin{array}{c}107.4 \pm \\
16.3\end{array}$ & $0.003^{* *}$ & $\begin{array}{c}107.88 \\
12.65\end{array}$ & $0.0002^{t+}$ \\
\hline DBP & $\begin{array}{l}69.24 \pm \\
10.57\end{array}$ & $\begin{array}{l}71.44 \pm \\
10.66\end{array}$ & 0.09 & $\begin{array}{l}70.72 \pm \\
13.02\end{array}$ & 0.34 & $\begin{array}{l}69.28 \pm \\
11.68\end{array}$ & 0.97 & $\begin{array}{l}70.68 \pm \\
10.91\end{array}$ & 0.19 \\
\hline $\mathrm{SaO}_{2}$ & $\begin{array}{c}97.52 \pm \\
1.19\end{array}$ & $\begin{array}{c}97.5 \pm \\
1.16\end{array}$ & 0.84 & $\begin{array}{c}97.2 \pm \\
1.29\end{array}$ & 0.09 & $\begin{array}{c}97.06 \pm \\
2.54\end{array}$ & 0.21 & $\begin{array}{c}97.5 \pm \\
1.01\end{array}$ & 0.91 \\
\hline $\mathrm{HR}$ & $\begin{array}{l}81.42 \pm \\
11.49\end{array}$ & $\begin{array}{l}80.8 \pm \\
10.56\end{array}$ & 0.54 & $\begin{array}{l}79.06 \pm \\
10.63\end{array}$ & $0.04^{\dagger}$ & $\begin{array}{l}80.36 \pm \\
10.02\end{array}$ & 0.42 & $\begin{array}{l}79.82 \pm \\
10.63\end{array}$ & 0.2 \\
\hline $\mathrm{RR}$ & $\begin{array}{c}15.92 \pm \\
3.55\end{array}$ & $\begin{array}{c}15.56 \pm \\
3.53\end{array}$ & 0.27 & $\begin{array}{c}15.6 \pm \\
3.59\end{array}$ & 0.31 & $\begin{array}{c}15.08 \pm \\
3.57\end{array}$ & $0.01^{* *}$ & $\begin{array}{c}15.06 \pm \\
3.65\end{array}$ & $0.02^{+\dagger}$ \\
\hline
\end{tabular}

Note: SBP: systolic blood pressure ( $\mathrm{mm} \mathrm{Hg}$ ); DBP: diastolic blood pressure ( $\mathrm{mm} \mathrm{Hg}$ ); HR: heart rate (bpm); RR: respiratory rate (rpm); $\mathrm{SaO}_{2}$ (\%): blood oxygen saturation; *: comparison between the $1^{\text {st }}$ set and the initial evaluation; ${ }^{+}$: comparison between the $2^{\text {nd }}$ and the initial evaluation; ${ }^{* *}$ : comparison between the $3^{\text {rd }}$ set and the initial evaluation; ${ }^{+\dagger}$ : comparison between the final and initial evaluation.

Source: Research data. 
$78.04 \pm 10.36 \mathrm{bpm}(\mathrm{p}=0.004)$, and RR from $16.28 \pm$ 3.91 to $15.16 \pm 3.73 \mathrm{rpm}(\mathrm{p}=0.003)$ (Table 2).

Comparing the variables at M1 in the research and the initial values at $M 3$, there was an increase in the $\mathrm{Pi}_{\max }$ from $66.2 \pm 26.37$ to $74.64 \pm 23.38 \mathrm{cmH}_{2} \mathrm{O}(\mathrm{p}=$ $0.002)$ and in the $\mathrm{Pe}_{\max }$ from $58.04 \pm 25.26$ to $68.4 \pm$ $25.34 \mathrm{cmH}_{2} \mathrm{O}(\mathrm{p}=0.0004)$.

There was an increase in the $\mathrm{Pi}_{\max }$ from $68.4 \pm 25.34$ to $78.4 \pm 24.9 \mathrm{cmH}_{2} \mathrm{O}(\mathrm{p}=0.008)$ and in the $\mathrm{Pe}_{\max }$ from $68.4 \pm 25.34$ to $71.04 \pm 27.89 \mathrm{cmH}_{2} \mathrm{O}(\mathrm{p}=0.04)$ when comparing the initial and final values at M3.
The cardiorespiratory variables collected at the initial (M1) and final (M4) evaluation are presented on Table 3.

When comparing M1 and M4 in the research, there was an increase in the $\mathrm{Pi}_{\text {max }}$ from $66.2 \pm 26.37$ to $81.24 \pm 25.68 \mathrm{cmH}_{2} \mathrm{O}(\mathrm{p}=6.87456 \mathrm{E}-06)$, in the $\mathrm{Pe}_{\max }$ from $58.04 \pm 25.26$ to $73.52 \pm 28.38 \mathrm{cmH}_{2} \mathrm{O}$ ( $p=1.47509 \mathrm{E}-05)$, decrease of the RR from 16.42 \pm 4.45 to $15.46 \pm 4.42 \mathrm{rpm}(\mathrm{p}=0.02)$, and increase of the VC from $4.40 \pm 0.96$ to $4.62 \pm 0.95 \mathrm{~L} / \mathrm{sec}$ ( $\mathrm{p}=$ 0.006) (Table 3).

Table 2 - Comparison between the cardiorespiratory variables: initial, final, and during the execution of each of the three sets of fifteen repetitions - M3.

\begin{tabular}{|c|c|c|c|c|c|c|c|c|c|}
\hline \multirow[b]{2}{*}{ Variables } & \multirow{2}{*}{$\begin{array}{c}\text { Initial } \\
\text { Evaluation } \\
\text { (at rest) }\end{array}$} & \multicolumn{6}{|c|}{ Sets } & \multirow{2}{*}{$\begin{array}{c}\text { Final } \\
\text { Evaluation } \\
\text { (at rest) }\end{array}$} & \multirow{2}{*}{$\begin{array}{c}\mathbf{p}^{\dagger \dagger} \\
\text { Value }\end{array}$} \\
\hline & & $\begin{array}{l}1^{\text {st }} \\
\text { Set }\end{array}$ & $\begin{array}{c}p^{*} \\
\text { Value }\end{array}$ & $\begin{array}{l}2^{\text {nd }} \\
\text { Set }\end{array}$ & $\begin{array}{c}\mathbf{p}^{\dagger} \\
\text { Value }\end{array}$ & $\begin{array}{l}3^{\text {rd }} \\
\text { Set }\end{array}$ & $\begin{array}{c}p * * \\
\text { Value }\end{array}$ & & \\
\hline SBP & $\begin{array}{c}110.52 \\
13.55\end{array}$ & $\begin{array}{c}106.48 \\
12.38\end{array}$ & $0.0001 *$ & $\begin{array}{c}107.82 \pm \\
13.6\end{array}$ & $0.02^{\dagger}$ & $\begin{array}{c}106.88 \\
13.56\end{array}$ & $0.0009 * *$ & $\begin{array}{c}106.48 \\
14.29\end{array}$ & $0.0006^{t+}$ \\
\hline DBP & $\begin{array}{l}67.04 \pm \\
10.04\end{array}$ & $\begin{array}{l}68.24 \pm \\
10.07\end{array}$ & 0.22 & $\begin{array}{c}68.92 \pm \\
9.85\end{array}$ & 0.15 & $\begin{array}{c}68.92 \pm \\
9.98\end{array}$ & 0.09 & $\begin{array}{l}68.56 \pm \\
10.10\end{array}$ & 0.19 \\
\hline $\mathrm{SaO}_{2}$ & $\begin{array}{l}9.46 \pm \\
1.01\end{array}$ & $\begin{array}{c}96.84 \pm \\
1.47\end{array}$ & $0.004^{*}$ & $\begin{array}{c}96.94 \pm \\
1.67\end{array}$ & $0.03^{\dagger}$ & $\begin{array}{c}96.8 \pm \\
2.09\end{array}$ & $0.01^{\star *}$ & $\begin{array}{c}96.52 \pm \\
4.78\end{array}$ & 0.17 \\
\hline $\mathrm{HR}$ & $\begin{array}{l}82.02 \pm \\
11.4\end{array}$ & $\begin{array}{l}80 \pm \\
10.88\end{array}$ & 0.16 & $\begin{array}{c}77.9 \pm \\
9.39\end{array}$ & $0.0001^{\dagger}$ & $9^{79.06 \pm}$ & $0.01 * *$ & $\begin{array}{l}78.04 \pm \\
10.36\end{array}$ & $0.004^{t \dagger}$ \\
\hline
\end{tabular}

Note: SBP: systolic blood pressure ( $\mathrm{mm} \mathrm{Hg})$; DBP: diastolic blood pressure ( $\mathrm{mm} \mathrm{Hg})$; HR: heart rate (bpm); $\mathrm{RR}$ : respiratory rate (rpm); $\mathrm{SaO}$ :

blood oxygen saturation (\%); *: comparison between the $1^{\text {st }}$ set and the initial evaluation; ${ }^{\dagger}$ :comparison between the $2^{\text {nd }}$ set and the initial evaluation; ${ }^{* *}$ : comparison between the $3^{\text {rd }}$ set and the initial evaluation; ${ }^{+t}$ : comparison between the final and initial evaluation.

Source: Research data.

Table 3 - Comparison of cardiorespiratory variables achieved by a single evaluation between Ml and M4.

(To be continued)

\begin{tabular}{|c|c|c|c|}
\hline \multirow[b]{2}{*}{ Variables } & \multicolumn{2}{|c|}{ Moments } & \multirow[b]{2}{*}{$p^{*}$ Value } \\
\hline & $\begin{array}{c}\text { M1 } \\
\text { Single Initial Evaluation }\end{array}$ & $\begin{array}{c}\text { M4 } \\
\text { Single Final Evaluation }\end{array}$ & \\
\hline SBP & $111.56 \pm 14.11$ & $111.44 \pm 15.55$ & 0.94 \\
\hline DBP & $70.24 \pm 10.61$ & $68.88 \pm 10.97$ & 0.35 \\
\hline$H R$ & $81.6 \pm 11.57$ & $81.86 \pm 10.90$ & 0.88 \\
\hline $\mathrm{RR}$ & $16.42 \pm 4.45$ & $15.46 \pm 4.42$ & $0.02^{*}$ \\
\hline $\mathrm{SaO}_{2}$ & $97.54 \pm 1.09$ & $97.38 \pm 1.29$ & 0.37 \\
\hline $\mathrm{Pi}_{\max }$ & $66.2 \pm 26.37$ & $81.24 \pm 25.68$ & $6.87456 \mathrm{E}-06^{\star}$ \\
\hline$P e_{\max }$ & $58.04 \pm 25.26$ & $73.52 \pm 28.38$ & $1.47509-05^{\star}$ \\
\hline
\end{tabular}


Table 3 - Comparison of cardiorespiratory variables achieved by a single evaluation between M1 and M4.

(Conclusion)

\begin{tabular}{lccc}
\hline & \multicolumn{2}{c}{ Moments } \\
\cline { 2 - 3 } Variables & M1 & M4 & p* Value \\
\hline Peak Flow & Single Initial Evaluation & Single Final Evaluation & 0.39 \\
VE & $323 \pm 100.14$ & $328.8 \pm 105.66$ & 0.15 \\
VT & $15.83 \pm 6.62$ & $14.79 \pm 5.21$ & 0.44 \\
VC & $1 \pm 0.44$ & $1.03 \pm 0.57$ & $0.006^{*}$ \\
\hline
\end{tabular}

Note: M1: moment 1; M4: moment 4; SBP: systolic blood pressure (mm Hg); DBP: diastolic blood pressure (mm Hg); HR: heart rate (bpm);

RR: respiratory rate (rpm); $\mathrm{SaO}_{2}$ : blood oxygen saturation (\%); $\mathrm{Pi}_{\text {max }}$ : maximal inspiratory pressure (cmH20); $\mathrm{Pe}_{\text {max }}$ : maximal expiratory pressure $\left(\mathrm{cmH}_{2} \mathrm{O}\right)$; VE: minute volume (L/min); VT: tidal volume (L); VC: vital capacity (L); *: comparison between moments 1 and 4. Source: Research data.

In variance analysis, only the $\mathrm{Pi}_{\max }$ and $\mathrm{Pe}_{\max }$ were significant $(\mathrm{p}<0.05)$, and there were no significant statistical alterations in the other variables.

\section{Discussion}

In this research, the cardiorespiratory effects caused by the use of the incentive spirometer by flow regarding the sets and repetitions were verified, especially in the SBP. Next, some notes concerning these findings will be discussed.

The lung and ribcage create a negative pressure in the pleural cavity through opposite elastic forces from both. This happens during spontaneous inspiration, facilitating the venous return and increasing the cardiac output, therefore strengthening the interconnection between the respiratory, cardiac, and vascular systems (19). The neurologic components enable this interaction as well once the central mechanisms, such as the afference of carotid baroreceptors, are also involved in the respiration control. There is scientific evidence that in humans the quality of the reflex action of the central respiratory baroreceptor depends on the level of activity of the afferent baroreceptor and on the depth of inspiration. The experiments suggest that the neural activity associated with the inspiration suppresses the efferent cardiac vagal activity in the central nervous system (20). The baroreceptors, while exercising, act to prevent high levels of BP, for as it increases, the dilation of arterial vessels activates the baroreceptors and produces a response that pumps the heart slower and induces compensatory dilation of the peripheral vascular tree, resulting in a decrease in BP towards normal levels (21). When there is an increase in the respiratory movements, such as while exercising, there is a decrease in the intrathoracic pressure and consequently increase in the final diastolic ventricular volume, increase in the systolic volume and increase in the cardiac output. During inspiration, there is a diaphragmatic contraction that increases abdominal pressure, facilitating blood movement towards the heart. Along with this mechanism, there is a decrease in the thoracic pressure with transference to the thoracic veins and right atrium. Thus, there is an increase in the pressure gradient between the veins located outside of the thorax and right atrium, resulting in an increase in venous return (22). Therefore, this is the explanation for the decrease in the SBP in this study that happened after the $2^{\text {nd }}$ and $3^{\text {rd }}$ sets and the final evaluation at $M 2$, and after the $1^{\text {st }}, 2^{\text {nd }}$, and $3^{\text {rd }}$ sets, and final evaluation at M3. Note that these decreases happened acutely (M2 and M3), however, at the final evaluation (M4), the systolic blood pressure levels remained stable with regard to the initial evaluation (M1).

Another topic to be discussed is the diastolic blood pressure (DBP) that had no alteration. This happened possibly because the increased venous return does not cause increase in the DBP, because the heart, that is managed by the sympathetic, pumps the blood deposited it quickly, which causes minimal or no pressure change (22). 
Continuing, there was also a decrease in the HR after the $2^{\text {nd }}$ set at $M 2$, after the $2^{\text {nd }}$ and $3^{\text {rd }}$ sets at M3, and in the final evaluation at M3. These cardiac changes can be explained by the signs from the baroreceptors that after entering the medulla oblongata, secondary signs stimulate the parasympathetic vagal center. The final effects are vasodilation of veins and arterioles in the entire peripheral circulatory system and decrease in the HR and the cardiac contraction force (22). What draws attention is that this can be observed from the second set at M2 and M3.

Concerning the respiratory variables, it was observed a decrease in the RR after the $3^{\text {rd }}$ set and final evaluation at $\mathrm{M} 2$, after the $2^{\text {nd }}$ and $3^{\text {rd }}$ sets and final evaluation at M3, and when comparing M4 and M1 in the research. It has been reported that the interaction of the cardiopulmonary control and carotid baroreflex of the vascular resistance, which in directly related to the respiratory control and blood pressure, is due to the neurocirculatory adjustments for compensation that were changed in large by simultaneous alterations in the cardiopulmonary vagal afferent firing (23). The mean RR in the studied sample is consistent with the expected normal standards ( 12 to $20 \mathrm{rpm}$ ) and, even if the RR is normal, the increase in pulmonary ventilation by the incentive spiromenter consequently also provides $\mathrm{RR}$ reduction. It is known that slow and steady breathing, below $10 \mathrm{rpm}$, affects the reflex control of the cardiorespiratory system and modulates the BP. More specifically, the lung inflation that increases with the decrease in RR allows the pulmonary stretch receptors to adapt. This neural activity serves as a signal to the marrow and is integrated with the information about the BP level generated by the arterial baroreceptors. As a severe response to the increase in BP and/or pulmonary insufflation, the heart rate decreases and vasodilation happens in the vascular territories (24). Ultimately, it is possible to note that there is an acute cardiovascular response to the slow and sustained respiration, as it happens with the use of the spirometers. In the suggested study, there was in both M2 and M3 decrease in RR, HR, and SBP among the sets and at the end of each moment.

As far as the respiratory pressure measurements, it was noted that there was an increase in $\mathrm{Pe}_{\max }$ after the three sets at M2, in $\mathrm{Pi}_{\max }$ and $\mathrm{Pe}_{\max }$ after the three sets at M3, and in $\mathrm{Pi}_{\max }$ and $\mathrm{Pe}_{\max }$ when compared M4 and $\mathrm{M} 1$ in the study. The increase in $\mathrm{Pi}_{\max }$ was already expected because the incentive inspirometer that was used in the study emphasizes the inspiratory muscles. Nevertheless the increase in expiratory pressure was a new finding, there is an explanation for such information as well. One feature in respiratory mechanics is the hydraulic connection between the diaphragm and the abdomen. Physiologically, any alteration in the intrathoracic pressure must be balanced by an opposite modification in the intra-abdominal pressure. To any given pulmonary volume, a downward movement of the diaphragm will have to go through a movement to the outside of the abdominal wall. So, the increase in the abdominal muscle tension immediately before inspiration may result in a more intense diaphragm contraction and in higher potential for the occurrence of greater differences in transdiaphragmatic pressure during the inspiration (25). In accordance with these statements, there is a close relation between the inspiratory and expiratory musculature, for that reason, when the inspiratory musculature is stimulated, indirectly the expiratory musculature is stimulated as well, a fact which determined increase in the levels of $\mathrm{Pe}_{\max }$. Moreover, the increase in $\mathrm{Pi}_{\max }$ and $\mathrm{Pe}_{\max }$ during the initial evaluation in M3 can be deriving from the repetitions, respiratory muscular strengthening, and learning. There is a study (26) that proves the increase in the $\mathrm{Pi}_{\max }$ values from the use of the respiratory incentives. Nonetheless, studies that prove the increase of the $\mathrm{Pe}_{\max }$ from the use of inspiratory incentives were not found.

At M4 in the research it is noted an increase in VC when comparing to M1. VC represents a measurement for ability and strength of the respiratory muscles $(27,28)$. Tarantino $(29)$ argues that isolated measurement of the $\mathrm{VC}$, as well as any other parameter, is of little value, but in this research it is possible to observe that there was an increase in the $\mathrm{Pi}_{\max }$ and $\mathrm{Pe}_{\max }$, variables that corroborate in establishing the increase in VC (29).

In this study there was also significant decrease in $\mathrm{SaO}_{2}$ after the $1^{\text {st }}, 2^{\text {nd }}$, and $3^{\text {rd }}$ sets at $\mathrm{M} 3$. This contrasts a study in which a significant increase in $\mathrm{SaO}_{2}(\%)$ (initial mean 96.06 \pm 1.14 and final 97.12 $\pm 1.36-\mathrm{p}<$ 0.05 ) was observed after the use of inspiratory incentives by flow and by volume (30). In this research, an increase in $\mathrm{SaO}_{2}$ was expected as well, because one of the inspiratory incentive objectives would be increase pulmonary ventilation which would raise $\mathrm{SaO}_{2}$, however that did not occur. It is believed that it happened because the $\mathrm{SaO}_{2}$ values are already high 
(initial mean $97.38 \pm 1.09$ and final $97.38 \pm 1.29$ )

and in the mentioned study those values were lower.

\section{Conclusion}

There are alterations in the cardiorespiratory and muscular parameters after the use of the incentive spirometer by flow, with significant alterations in SBP, $\mathrm{HR}, \mathrm{RR}, \mathrm{SaO}_{2}, \mathrm{Pi}_{\max }$ and $\mathrm{Pe}_{\max }$, happening more frequently in the sets with 15 repetitions.

\section{References}

1. Carvalho M. Fisioterapia respiratória: fundamentos e contribuições. 5. ed. Rio de Janeiro: Revinter; 2001.

2. Bethlem N. Pneumologia. 4. ed. São Paulo: Atheneu; 2000.

3. West JB. Fisiologia respiratória: princípios básicos. 8. ed. São Paulo: Artmed; 2010.

4. Costa D. Fisioterapia respiratória básica. Rio de Janeiro: Atheneu; 1999.

5. Parreira VF, Coelho EM, Tomich GM, Alvim AMA, Sampaio RF, Britto RR. Avaliação do volume corrente e da configuração toracoabdominal durante o uso de espirômetros de incentivo a volume e a fluxo, em sujeitos saudáveis: influência da posição corporal. Rev bras fisioter. 2004;8(1):45-51.

6. Freitas ERFS, Soares BGO, Cardoso JR, Atallah AN. Espirometría estimulada para la prevención de las complicaciones pulmonares después de la revascularización arterial coronária (Revisión Cochrane traducida). La Biblioteca Cochrane Plus. 2008;(4).

7. Carvalho CRF, Paisani DM, Lunardi AC. Incentive spirometry in major surgeries: a systematic review. Rev bras fisioter. 2011;15(5):343-50.

8. Guimarães MMF, El Dib RP, Smith AF, Matos D. Incentive spirometry for prevention of postoperative pulmonary complications in upper abdominal surgery. Cochrane database syst rev. 2009;(3):(CD006058). doi: 10.1002/14651858.CD006058.pub2.

9. AARC (American Association for Respiratory Care) clinical practice guideline. Incentive spirometry. Respir care. 1991;36(12):1402-5.
10. Mahan LK, Scott-Stum S. Krause: alimentos, nutrição \& dietoterapia. 9. ed. São Paulo: Roca; 1998.

11. Cronk CE, Roche AF. Race- and sex-specific reference data for triceps and subscapular skinfolds and weight/stature. Am J Clin Nut. 1982;35(2):347-54.

12. Who Expert Consultation. Appropriate body-mass index for Asian populations and its implications for policy and intervention strategies. Lancet. 2004; 363:157-63.

13. Sociedade Brasileira de Cardiologia, Sociedade Brasileira de Hipertensão, Sociedade Brasileira de Nefrologia. VI Diretrizes Brasileiras de Hipertensão Arterial. Arq Bras Cardiol. 2010; 95(1 supl 1):1-51.

14. Leiner GC, Abramowitz S, Small MJ, Stenby VB, Lewis W. Expiratory peak flow rate. Standard values for normal subjects. Use as a clinical test of ventilatory function. Am Rev Respir Dis. 1963;88:644-51.

15. Azeredo CAC. Fisioterapia respiratória no hospital geral: expansão, reexpansão, recrutamento alveolar. São Paulo: Manole; 2000.

16. Britto RR, Brant TCS, Parreira VF. Recursos manuais e instrumentais em fisioterapia respiratória. São Paulo: Manole; 2008.

17. Scanlan CL, Wilkins RL, Stoller JK. Fundamentos da terapia respiratória de Egan. 7. ed. São Paulo: Manole; 2000.

18. Milone G. Estatística: geral e aplicada. São Paulo: Thomson; 2006.

19. Dragosavac D, Terzi RGG. Interação cardiopulmonar durante a ventilação mecânica. In: Carvalho CRR, organizador. Ventilação mecânica básica. São Paulo: Atheneu; 2006. p. 253-69.

20. Eckberg DL, Orshan CR. Respiratory and baroreceptor reflex interactions in man. J Clin Invest. 1977;59(5):780-5.

21. McArdle WD, Katch FI, Katch VL. Fisiologia do exercício: energia, nutrição e desempenho humano. 4. ed. Rio de Janeiro: Guanabara Koogan; 1998.

22. Guyton AC, Hall JE. Tratado de fisiologia médica. 10.ed. Rio de Janeiro: Guanabara Koogan; 2002.

23. Victor RG, Mark AL. Interaction of cardiopulmonary and carotid baroreflex control of vascular resistance in humans. J Clin Invest. 1985;76:1592-8. 
24. Schein MH, Gavish B, Herz M, Rosner-Kahana D, Naveh P, Knishkowy B, et al. Treating hypertension with a device that slows and regularises breathing: a randomised, double-blind controlled study. J Hum Hypert. 2001;15(4):271-8.

25. Norkin CC, Levangie PK. Articulações: estrutura e função: uma abordagem prática e abrangente. 2.ed. Rio de Janeiro: Revinter; 2001.

26. Kotz JC. Estudo comparativo do efeito dos incentivadores respiratórios VOLDYNE ${ }^{\circledR}$ e RESPIRON ${ }^{\circledR}$ sobre a força dos músculos inspiratórios em indivíduos saudáveis [monografia]. Cascavel: Unioeste; 2005.

27. Azeredo CAC. Avaliação clínica dos músculos respiratórios. In: Azeredo CAC, organizador. Técnicas para o desmame noventilador mecânico. São Paulo: Manole; 2002. p. 38-9.
28. Azeredo CAC, Machado MGR. Fisioterapia respiratória moderna. 3. ed. São Paulo: Manole; 1999.

29. Tarantino AB. Diagnóstico Funcional. In: Tarantino $\mathrm{AB}$, organizador. Doenças Pulmonares. 4. ed. Rio de Janeiro: Guanabara Koogan; 1997. p. 147-60.

30. Parreira VF, Tomich GM, Britto RR, Sampaio RF. Assessment of tidal volume and thoracoabdominal motion using volume and flow-oriented incentive spirometers in healthy subjects. Braz J Med Biol Res. 2005;38(7):1105-12.
Received: 06/15/2013

Recebido: 15/06/2013

Approved: 01/03/2014

Aprovado: 03/01/2014 